\title{
EITUSE VÄLJENDAMISE VORMIVALIKUTEST XVII-XVIII SAJANDI PÕHJAEESTI TEKSTIDES
}

\author{
LIINA PÄRISMAA
}

$\mathrm{A}$ rtikkel käsitleb lauseeituse väljendamist põhjaeesti kirjakeele vaimulikes ning õpetlikes tekstides. Lauseeituse all peetakse silmas eitust, mille mõjualasse kuulub kogu lause, nt Täna ajalehed ei ilmu, ent selle hulka arvestatakse ka negatsioon, mille fookuses on mõni muu lauseelement, mida tähistatakse nt partikliga mitte või rõhutamisega, nt Laps ei vaja mitte maiustusi, vaid armastust (Erelt 2017: 181, 186-187). Erinevalt tänapäeva eesti kirjakeelest, kus negatsiooni vormistatakse põhiliselt eitussõnaga ei (Erelt 2017: 182), võis eesti vanemas kirjakeeles $e$-tüvelise eitussõna kasutus varieeruda (nt $e p$, ei, es, eks) ning negatsiooni väljendati ka tarinditega, mida praegu enam ei kasutata, nt partikliga mitte ja pöördetunnusega verbiga. Seepärast on eitus uurimisainesena aktuaalne ja huvitav: selle varieeruva morfosüntaktilise nähtuse uurimine võimaldab jälgida tollases kiiresti arenevas kirjakeeles toimunud muutusi ning vaagida nende võimalikke põhjusi.

Varasematest uurijatest on eesti vanema kirjakeele negatsiooni ja pöörduva eitusverbi ajaloolise taandumise protsessi käsitlenud Katja Ziegelmann (2008, 2011); Pille Penjam (2010) on uurinud lauseeituse vormistamist XVII sajandi põhjaeesti autori Heinrich Stahli teose „Hand- vnd Haußbuch” kolmandas osas ning Annika Kilgi (2012) on vaadelnud negatsiooni edasiandmist erinevates lõuna- ja põhjaeesti piiblitõlgetes alates XVII sajandi algusest kuni 1739. aasta täispiiblini. Kuigi nendes on eitust põhjalikult käsitletud eri vaatepunktidest, ei ole laiemalt keskendutud vormivõimaluste varieerumisele ja varieerumise ulatuse väljaselgitamisele. Samas on eitus üheks indikaatornähtuseks, mille varieerumist uurides saab kirjeldada XVII sajandi lõpul põhjaeesti kirjakeeles alanud reformi morfosüntaktilist poolt, sest tegu on sagedase tarindiga.

Siinse artikli eesmärk on kirjeldada, missuguste partikliliste tarinditega väljendatakse lauseeitust, kas ja kuidas nende kasutus XVII-XVIII sajandi jooksul teiseneb ning milline on varieeruvuse ulatus. Samuti vaadeldakse muutusi põhiverbi vormis. Metodoloogiliselt on eesmärk kontrollida, kas valim sobib morfosüntaktiliste nähtuste, k.a eituse uurimiseks. Siinne artikkel on osa suuremast uurimusest, kus vaadeldakse erinevate morfosüntaktiliste nähtuste varieerumist põhjaeesti vanemas kirjakeeles tollase kirjakeele standardi kujunemisel ning normi arengut mõjutanud kiriklike autorite rolli selles. Seni puudub ülevaatlik uurimus, mis koondaks morfosüntaksi tasandi nähtuste varieerumise andmeid XVII-XVIII sajandi põhjaeesti kirjakeelt enim mõjutanud kirjameeste teostes.

Artikli järgnevas osas käsitletakse eesti vanemat kirjakeelt ja sealseid eituse väljendamisega seotud küsimusi. Teises osas tutvustatakse uurimis- 
materjali ning kasutuspõhist meetodit, millest analüüsil lähtuti. Kolmandas osas antakse ülevaade uurimise tulemustest ning neljas osa võtab need tulemused kokku.

\section{Eesti vanem kirjakeel ning eituse väljendamise problemaatika}

Eesti kirjakeele traditsiooni alguseks loetakse XVI sajandit, kui algas usupuhastus ning levima hakkas trükikunst. Tekkinud kirjakeeli oli kaks: põhjaning lõunaeesti keel. (Laanekask 2004: 15-16) Põhjaeesti keel domineeris Eestimaa kubermangus ja Liivimaa kubermangu põhjaosas ning lõunaeesti keel hõivas Liivimaa kubermangu lõunaosa (Piiblikonverentsid 2003: 9).

Kujunev eesti kirjakeel oli saksamõjuline ning usulise loomuga. Tegemist oli vaimuliku erialakeelega (Ross 2009: 553). Ilmalikke tekste oli vähe, nt juhuluule või mõned ametivanded (Raag 2008: 34). Eesti kirjakeele loojad olid saksa päritolu kirikuõpetajad, kes seda ka aktiivselt kasutasid, nt tõlkisid kristlikke teoseid või pidasid jutlusi (Ross 2009: 553). Eestlastest vaimulikkond puudus ning kohalikud olid passiivses vastuvõtja rollis (Ross 2011: 117, 2009: 553).

Eesti kirjakeele areng ning arendamine ei kulgenud probleemideta. XVII sajandi keskpaigaks oli kirjakeel mõningal määral ühtlustunud, kuid varieeruvust ja ebajärjekindlust põhimõtetes oli siiski veel palju (Lill 1988: 14-15, 17). Üheks varieeruvaks ning lahkarvamusi tekitanud valdkonnaks oli eitus. Esines tõlkeraskusi, mis olid tingitud saksa ja eesti eitusväljendite erinevusest, kuid nõutus võis piiblitõlkijatel tulla ka negatsioonivormide piirkondlikust varieerumisest. (Penjam 2010: 141; Kilgi 2012: 107, 110) Seetõttu tekkisid mitmed isesugused eitustarindid, nt kasutati konnegatiivse verbivormi asemel pöördetunnusega vormi (nt ep sahn ) või anti negatsiooni edasi partikliga mitte ja jaatava verbivormiga (nt see mitte on) (Penjam 2010: 141-142).

1680. aastatel algas põhjaeesti kirjakeeles murrang rahvapärasuse suurendamise ja saksapärasuste vähendamise suunas (Ross 2013: 212). Aktiivsemalt avaldati eestikeelseid teoseid ning arutleti keeleküsimuste üle (Tafenau 2011: 41). Piibli tõlke- ja keeleküsimustes olid Eesti- ja Liivimaa konsistooriumi esindajad eriarvamusel, mistõttu tekkis kaks koolkonda. Eestimaa koolkonna esindajad pooldasid sihtkeele senist saksapärast varianti, kuid Liivimaa koolkonna omad rahvapärasemat. (Ross 2013: 211) Korraldati kaks piiblikonverentsi (1686 Liepas, 1687 Pilistveres), kus arutleti Stahli-pärases eesti keeles piiblitõlke üle, kuid ühistele seisukohtadele seal ei jõutud ning arutelud jätkusid ka pärast konverentse (Piiblikonverentsid 2003: 10-11; Ross 2007: 546). Piiblikonverentsidel leidis käsitlemist ka negatsioon. Villem Reiman (1895: 18) ja Arnold Kask (1970: 66) toovad välja, et Bengt Gottfried Forselius esitas esimesel piiblikonverentsil mitmeid kirjaviisi parandamise ettepanekuid. ${ }^{1}$ Lisaks ortograafia rahvapärastamisele tegi ta ettepaneku tarvitada eituse väljendamisel konnegatiivset verbivormi, nt minna ep tahha, kuid kumbki neist ei saanud Eestimaa konsistooriumilt positiivset vastukaja (Piiblikonve-

1 Tema käsikiri pole säilinud, kuid on olemas Eestimaa konsistooriumi koosoleku protokoll, kus tema ettepanekute üle arutletakse (Kask 1970: 65; vt ka Piiblikonverentsid 2003: 88-101). 
rentsid 2003: 89-90, 93). Tema ettepanekuid arutati ka teisel piiblikonverentsil, kuid üksmeelt nende suhtes ei saavutatud sealgi (Kask 1970: 68).

Põhjaeestikeelne Uus Testament ilmus pärast rohket toimetamistööd 1715. aastal. Anton Thor Helle ja Heinrich Gutsleffi toimetamisel anti Uus Testament 1720. aastatel teistkordselt välja ning jõudis sellisel kujul ka täispiiblisse. (Ross 2009: 556, 2013: 211) Tollast eesti vaimuliku kirjakeele ideaali väljendas 1739. aastal ilmunud eestikeelne täispiibel, mis Kristiina Rossi sõnul on „tänini eesti kirjakeele ainsaks kõrgkihistuseks” (Ross 2007: 548).

\section{Materjal ja meetod}

Tartu Ülikooli vana kirjakeele korpuse (edaspidi VAKK) märgendamata osast valiti uurimiseks juhuslikult 300 eitustarindi näidet XVII sajandi põhjaeesti tekstidest ning sama palju XVIII sajandi põhjaeesti teostest (korpuse kohta täpsemalt vt Kingisepp jt 2004). Seejärel märgendati kogu uurimismaterjal käsitsi: märgiti ära eitustarindis esineva põhiverbi vorm, täis- ja ennemineviku korral lisati info abiverbi vormi kohta, samuti tähistati märgendiga eitussõna esinemiskuju ning partikli mitte leidumine teiste negatsiooni moodustavate partiklitega konstruktsioonides.

XVII sajandi negatsiooni väljendavad tarindid pärinevad vaimulikest tekstidest ning XVIII sajandi omad vaimulikest ja õpetlikest teostest. XVII sajandi põhjaeesti materjalis on selle aja põhiliste põhjaeesti autorite tekstid: Georg Mülleri jutlused (1600-1606), Heinrich Stahli käsiraamat „Hand- vnd Haußbuch” I-IV (1632-1638) ning jutlusekogu „Leyen Spiegel” I-II (1641, 1649) ja Christoph Blume vaimulikud teosed „Das Kleine Corpus Doctrinæ” (1662) ning „Geistliche Hohe Fäst-Tahgs Freude” (1667). Christoph Blume tekstidest jäid välja „Geistliche Wochen-Arbeit” (1666) ja „Geistliche Seelen Ergötzung" (1667), kuna nende kohta ei olnud võimalik VAKK-is otsingut teha.

XVIII sajandi põhjaeesti teostest uuriti 1715. aasta Uut Testamenti, Anton Thor Helle töö „Kurtzgefaszte Anweisung Zur Ehstnischen Sprache” (1732) 5. osa „Colloquia Esthonica” õpetlikke dialooge ning 1739. aasta täispiiblit. Kõige hilisemaks allikaks valiti täispiibel, kuna see teos on tolleks ajaks välja kujunenud kirjakeele standardi tähiseks (Ross 2009: 557).

Vaadeldavad näited on erinevas kõneviisis, ajas ja eri tüüpi lausetes. Kuna uurimuses keskenduti $e$ - ja $i$-tüvelise partikliga vormistatud eitustarinditele, ei ole artiklis käsitletud ainult pronoomeniga (nt keegi, ükski) väljendatavaid negatsioonivorme. Samuti on käsitlusest välja jäetud eitavad laused või fraasid, kus verb puudub (nt ainult eitussõna sisaldavad päringuvastused), kuna varieeruvust uurides taheti muu hulgas jälgida, kas verbivorm on konnegatiivne või pöördetunnusega.

Materjali uuriti kasutuspõhise teooria raamistikus, mis vaatleb keelt muutuva ja dünaamilisena ning lähtub hüpoteesist, et kasutusjuhud avaldavad ühtlasi mõju keele kognitiivsele süsteemile (Bybee, Beckner 2010: 854; Bybee 2010: 14). Kuna mõju on igal keelekasutusjuhul, väljendub variatsioon

${ }^{2}$ Kuigi teosel „Kurtzgefaszte Anweisung Zur Ehstnischen Sprache” on mitu autorit, viidatakse sellele tööle siin ja edaspidi traditsiooniliselt Anton Thor Helle nime järgi, kuna teiste autorite panus peale Eberhard Gutsleffi ei ole teada. 
ning muutus keelekasutaja süsteemis otseselt. Muutused on järkjärgulised ning toimuvad keele kasutamise käigus. (Bybee 2010: 9, 114) Mida suurema sagedusega mingi üksus või muster on, seda sügavamalt on see kasutuses juurdunud ning seega on ka tõenäolisem, et keelekasutaja neid uuesti tarvitab (Barlow, Kemmer 2000: x; Coussé, Mengden 2014: 8).

\section{Eituse partiklilised väljendusvahendid XVII-XVIII sajandi põhjaeesti tekstides}

XVII-XVIII sajandi põhjaeesti autorite teostes leiduvate kõigi partikliliste eitustarindite osakaal protsentides on näha joonisel 1. Andmaks selgemat pilti nende esinemisest, on arvestatud eitussõnade ja -vormide - ep/eb, pöörduv eitusverb, ei, is, es, polle, erra / ärra, ep-keeld, eps ja eks - hulka ka konstruktsioonid, kus need esinevad koos partikliga mitte.

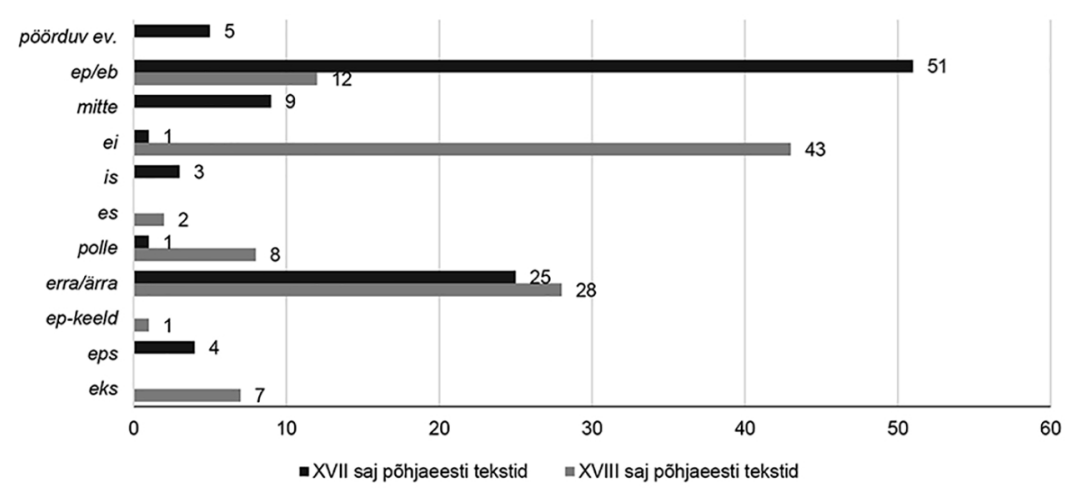

J o o n is 1. Eituse väljendamine XVII-XVIII sajandi põhjaeesti tekstides protsentides.

\subsection{Pöörduv eitusverb}

Pöörduva eitusverbiga moodustati XVII sajandi põhjaeesti tekstides negatsiooni 5\%-1 valimis esindatud juhtudest (vt joonist 1). Pöörduva eitusverbiga eitust leidus Mülleri (näide 1) ning Stahli tekstides. Mülleri jutlustest olid valimis mitmuse esimese ja kolmanda pöörde näited, mis on Külli Prillopi (2001: 77) järgi ainsad Mülleril esinevad pöörduva eitusverbi vormid. Stahli kirjutistes olid ainsuse esimese ja mitmuse kolmanda pöörde verbivormid, mis „Heinrich Stahli tekstide sõnastiku” järgi (Habicht jt 2015: 62) on ainsad pöörduva eitusverbi vormid, mida Stahl tarvitas. Partikkel mitte toimis pöörduva eitusverbiga lausetes negatsiooni rõhutajana.

(1) [---] næmat ewat olle sest mitte tædtnut echk kulnuth. 'nad ei ole seda mitte teadnud või kuulnud' (VAKK, Müller9 1603: 5) 
Põhiverb võis pöörduva eitusverbiga lauses olla nii konnegatiivne kui ka pöördetunnusega (vt tabelit 1). Konnegatiivset põhiverbi leidus pöörduva eitusverbiga näidetes neljal korral ning pöördetunnusega põhiverbi kaheksal korral. Autoriti vaatlusel ilmnes, et Müller eelistas tarvitada konnegatiivset ning Stahl pöördetunnusega põhiverbi: kõik konnegatiivse põhiverbi näited pöörduva eitusverbiga lausetes on Müllerilt ning enamik pöördetunnusega põhiverbi näidetest Stahli tekstidest (7 korral). Minevikuvormis põhiverbe esines pöörduva eitusverbiga lausetes neljal korral.

Tabel 1

Põhiverbi vormi sagedus pöörduva eitusverbiga negatsioonitarindites

\begin{tabular}{|l|c|c|c|}
\hline Autor & $\begin{array}{c}\text { Konnegatiivne } \\
\text { põhiverb }\end{array}$ & $\begin{array}{c}\text { Pöördetunnusega } \\
\text { põhiverb }\end{array}$ & $\begin{array}{c}\text { Põhiverbi } \\
\text { minevikuvormid }\end{array}$ \\
\hline Müller & 4 & 1 & 2 \\
\hline Stahl & - & 7 & 2 \\
\hline Kokku & 4 & 8 & 4 \\
\hline
\end{tabular}

Blume teostest pöörduva eitusverbiga negatsioonitarindeid valimisse ei sattunud. Ka hilisemal kontrollimisel ei tulnud VAKK-i märgendamata osa otsingust Blume tekstidest pöörduva eitusverbi kohta ühtegi vastet.

Katja Ziegelmanni dissertatsioonist (2011: 198, 422) nähtub, et pöörduvat eitusverbi leidus põhjaeesti tekstides kuni XVII sajandi keskpaigani ning selle kadumine eesti keelest oli keelesisene protsess. Blume esimene trükitud töö „Das Kleine Corpus Doctrinæ” pärineb aastast 1662 ehk umbes ajast, millal pöörduv eitusverb kirjakeelest taandus. Samas on tolle aja grammatikates veel pöörduva eitusverbi vorme välja toodud (vt nt Göseken 1660: 70; Hornung 1693: 93). Ka Kilgi (2012: 119) uurimusest ilmneb, et XVII sajandi lõpu piibliversioonides (nt Müncheni käsikirjas ${ }^{3}$ ) oli pöörduv eitusverb vähesel määral olemas. Seega seda eitusvormi teati, kuid selle kasutamist oli hakatud kirjakeele tekstides vähendama.

XVIII sajandi põhjaeesti teostest pöörduvat eitusverbi valimisse ei sattunud. Ilmselt on see vorm XVIII sajandil täielikult põhjaeesti kirjakeele vaimulikest ja õpetlikest tekstidest kadunud. Sellele viitab pöörduva verbivormi puudumine Helle kui ühe tolle aja autoriteetsema keelemehe ja tema kaasautorite 1732. aasta keeleõpetuse „Kurtzgefaszte Anweisung Zur Ehstnischen Sprache" negatsiooni väljendamise ja eitavate adverbide grammatikaosas (Helle 1732: 35-37, 40, 57).

\subsection{Ep/eb}

Valimist ilmnes, et XVII sajandi põhjaeesti tekstides oli põhiline eituspartikliga ep vormistatud konstruktsioon (näide 2), mille abil moodustati $51 \%$ eitustarinditest. $E p$-negatsiooni esines kõigi vaadeldud XVII sajandi põhjaeesti

${ }^{3}$ Müncheni käsikiri (1694) on Johann Hornungi Uue Testamendi tõlke üks ärakirjadest (Reila 2007: 556). 
autorite tekstides. Ka autoriti uurides selgus, et selle aja kirjamehed väljendasid lauseeitust enim sõnaga ep (v.a eitavates käsklausetes). Mitte toimis selle partikliga koos negatsiooni fookustaja või rõhutajana.

(2) Christus ep tullep mitte tühjast / erranis tohp ilusat andet hennesse kahs. 'Kristus ei tule mitte tühjalt, vaid toob enesega ilusad annid' (VAKK, Stahl 1641: 416)

Leidus nii jaatusega sümmeetrilist kui ka asümmeetrilist eitust (vt tabelit 2). Sümmeetrilise eituse puhul puuduvad jaatavas ja eitavas lauses struktuurierinevused, nt sks ich singe - ich singe nicht 'ma laulan - ma ei laula'. Asümmeetrilises negatsioonis on aga erinevused eitava ja jaatava lause struktuuris olemas, nt sm laulan - en laula 'ma laulan - ma ei laula'. (Miestamo 2005: 51-53, 2009: 215-216)

Materjalist ei ilmnenud, et XVII sajandil oleks partikliga ep eituskonstruktsioonis ühte verbivormi selgelt teistele eelistatud. Põhiverb pöördus ep-eituses 66 korral ning oli konnegatiivne 61 korral. Minevikuvormis esines põhiverb 19 korral. Autoriti vaadeldes paistis põhiverbi vormi valikuga silma Müller, kes erinevalt Stahlist ja Blumest eelistas enamasti kasutada konnegatiivset verbivormi (51 korral), mis osutab tema keelekasutuse mõneti suuremale rahvapärasusele.

Tabel 2 .

Põhiverbi vormi sagedus partikliga $e p$ eitustarindites

\begin{tabular}{|l|c|c|c|c|}
\hline Autor & $\begin{array}{c}\text { Konnegatiivne } \\
\text { põhiverb }\end{array}$ & $\begin{array}{c}\text { Pöördetunnusega } \\
\text { põhiverb }\end{array}$ & $\begin{array}{c}\text { Pöördetunnuseta } \\
\text { põhiverbi vormid }\end{array}$ & $\begin{array}{c}\text { Põhiverbi } \\
\text { mineviku- }_{\text {vormid }}\end{array}$ \\
\hline Müller & 51 & 10 & 2 & 11 \\
\hline Stahl & 5 & 42 & 3 & 6 \\
\hline Blume & 5 & 14 & 1 & 2 \\
\hline Kokku & 61 & 66 & 6 & 19 \\
\hline
\end{tabular}

${ }^{1}$ Pöördetunnuseta põhiverbi vormides puudub pöördetunnus olemuslikult, nt ainsuse 3. pöörde konditsionaalivormis.

XVIII sajandi põhjaeesti tekstides oli partikli ep kasutamine eituse moodustamiseks vähenenud 39\% võrra. Seda eitussõna leidus selle aja valimis vaid $12 \%$-l juhtudest (vt joonist 1 ). $E p$-negatsiooni moodustati kolmest XVIII sajandi põhjaeesti tekstist kahes: 1715. aasta Uues Testamendis ning 1739. aasta täispiiblis (näide 3). Sarnaselt XVII sajandi põhjaeesti teostega oli partiklil mitte fookustav või rõhutav funktsioon.

(3) Minna ep otsi mitte omma Auo / aga üks on / ke seda otsib [---] (VAKK, UT 1715: Jh [VIII] 50)

Helle 1732. aasta teose dialoogide osast eitussõnaga ep vormistatud negatsiooni valimisse ei sattunud. Hilisemal kontrollimisel leiti VAKK-ist Helle 
1732. aasta keeleõpetuse 5. osast vaid kolm partikliga ep väljendatud eitust, samal ajal kui eitussõnaga ei näiteid oli ligikaudu 30. Partiklite osa adverbikäsitluses on negatiivina ei kõrval välja toodud ka eitussõna ep (lisaks vormidele es ja ära) (Helle 1732: 35-37, 40, 57). Seega osutab nii siinses uurimuses leitu kui ka partikli ep vähene väljatoomine Helle 1732. aasta keeleõpetuse grammatikaosas, et selles teoses on eelistatud negatsiooni edasi anda algselt ainult lõunaeesti tekstides levinud ei-vormiga.

XVIII sajandi põhjaeesti tekstides oli muutusi toimunud ka põhiverbi vormis. Kui XVII sajandi põhjaeesti teostes esines ep-eituse korral põhiverb peaaegu võrdselt nii konnegatiivsena kui ka pöördetunnusega (vastavalt 61 ja 66 korda), siis XVIII sajandi põhjaeesti allikates oli põhiverb ainult konnegatiivne. Seega oli XVIII sajandil ka negatsiooni verbivormi valikul pöördutud kindlamalt eestipärasemate asümmeetriliste eitusvormide juurde. Juba Johann Hornung märgib oma 1693. aasta grammatikas, et partikliga ei või ep koos kasutades kaob verbidel lõpukonsonant, nt Minna ei olle (Hornung 1693: 74).

\subsection{Mitte}

Negatsiooni võidi XVII sajandi põhjaeesti tekstides väljendada ka ainult partikliga mitte, milles on näha saksa keele eeskuju, kus negatsioon on jaatusega sümmeetriline.

Eituse väljendamiseks kasutasid partiklit mitte kolmest selle aja põhjaeesti autorist kaks: Stahl ning Blume (näide 4). Mülleri jutlustest mitte-eitust valimisse ei sattunud. Kokku leidus mitte-negatsiooni 9\%-1 kõigist valimisse kuulunud XVII sajandi põhjaeesti teoste näidetest (vt joonist 1).

(4) Meije Jummal tullep nink jehp mitte waid [---] (Unser GOtt kömt und schweiget nich[t.] [---]) 'Meie Jumal tuleb ning ei vaiki' (VAKK, Blume 1662: 179)

Oodatult oli partikliga mitte eituslausetes ainult jaatusega sümmeetriline negatsioon nagu eeskujuks olevas saksa keeleski. Põhiverb oli pöördetunnusega 28 korral, ühel korral oli tegu pöördetunnuseta konditsionaalivormiga.

Vastupidiselt XVII sajandi põhjaeesti tekstidele ei esinenud XVIII sajandi põhjaeesti kiriklikes ega õpetlikes teostes mitte enam lauses ainsa negatsiooni vormistava vahendina. Kilgi (2012: 121-122) järgi kadus mitte-eitus peaaegu täielikult alates 1694. aasta Müncheni käsikirjast. Ka Hornungi aasta varasemas grammatikas ega Helle 1732. aasta keeleõpetuses ei leidunud partiklit mitte üksi negatsiooni väljendajana. See partikkel esines nendes teostes koos eitussõnaga (vt nt Hornung 1693: 93; Helle 1732: 57). Seega oli XVIII sajandi põhjaeesti kirjakeele tekstides eemaldutud saksapärastest jaatusega sümmeetrilistest eituskonstruktsioonidest. 


\section{4. $E i$}

Ainus XVII sajandi põhjaeesti autor, kes valimis partikliga ei negatsiooni vormistas (näide 5), oli Blume, kes on ka hiliseim uurimuses käsitletud XVII sajandi põhjaeesti kirjameestest. Ei-eitust esines vaid 1\% (kokku kolm näidet Blume 1667. aasta teosest „Geistliche Hohe Fäst-Tahgs Freude”). VAKK-i märgendamata osast ei leitud hilisemal kontrollimisel Blume 1662. aasta tööst ühtegi ei-eituse näidet. Samas ilmnes 1666. aasta teksti „Geistliche WochenArbeit" (vt nt Blume 1666: 56) pistelisest kontrollist, et sealgi on Blume väljendanud negatsiooni partikliga $e i$.

(5) [---] Et olet Surmast tousnut Sa \# ma Hauwas ei sahn jehma [---] (VAKK, Blume 1667: 80)

Põhiverb oli valimis ei-eituse korral kahel juhul konnegatiivne ning ühel juhul pöördetunnusega. Partiklit mitte Blume eituse intensiivistamiseks kasutanud polnud.

$E i$ kasutuselevõtt võis Blumel olla tingitud selle sõna paremast häälduslikust sobivusest lauludesse, sest kõik kolm näidet pärinevad vaimulikest lauludest. $E i$ lõpeb täishäälikuga, mistõttu kõlab meloodilisemalt kui ep.

Nagu partikli ep, nii ka ei kasutuses oli XVIII sajandi põhjaeesti teostes toimunud muutusi (vt joonist 1): ei-eituse esinemus suurenes 1\%-lt 43\%-le. Sarnaselt Kilgi käsitluse tulemustega (2012: 117, 123) oli ei ka siinse uurimuse andmetel XVIII sajandil enim tarvitatav vorm eituse väljendamiseks. Partikliga $e i$ vormistati negatsioon kõigis kolmes valimisse kuulunud XVIII sajandi põhjaeesti tekstis (näide 6). Partikkel mitte lisati eitussõnaga ei konstruktsiooni negatsiooni tugevdamiseks või fookustamiseks 50 korral ning see puudus 80 korral.

(6) Nemad ei pea mitte mo hingamisse sisse sama. (VAKK, Piibel 1739: 2Jh [IV] 5)

Tabel 3 .

Põhiverbi vormi sagedus partikliga $e i$ eitustarindites

\begin{tabular}{|l|c|c|c|c|}
\hline Tekst & $\begin{array}{c}\text { Konnegatiivne } \\
\text { põhiverb }\end{array}$ & $\begin{array}{c}\text { Pöördetunnusega } \\
\text { põhiverb }\end{array}$ & $\begin{array}{c}\text { Pöörde- } \\
\text { tunnuseta } \\
\text { põhiverbi } \\
\text { vormid }\end{array}$ & $\begin{array}{c}\text { Põhiverbi } \\
\text { mineviku- } \\
\text { vormid }\end{array}$ \\
\hline 1715. a UT & 30 & 2 & 3 & 4 \\
\hline $\begin{array}{l}\text { 1732. a keele- } \\
\text { opptus }\end{array}$ & 14 & - & 1 & 2 \\
\hline $\begin{array}{l}\text { 1739. a } \\
\text { täispiibel }\end{array}$ & 57 & - & 4 & 13 \\
\hline Kokku & 101 & 2 & 8 & 19 \\
\hline
\end{tabular}


$E i$-eitusega lausetes esines peamiselt jaatusega asümmeetriline negatsioon, põhiverbi vorm oli konnegatiivne 101 korral ning vaid kahel korral oli kasutatud pöördetunnusega vormi (vt tabelit 3). Mõlemad pöördetunnusega vormid pärinesid 1715. aasta Uuest Testamendist: ühel korral oli lisatud pöördetunnus konditsionaali 1. pöörde vormile ning teisel korral oli tegu indikatiivivormiga. Minevikuvormis põhiverbe leidus 19 korral. Nagu eelnevalt osutatud, anti põhjaeestikeelne Uus Testament arvukate toimetamiste järel välja 1715. aastal. Kristiina Ross märgib, et see teos sisaldab kogu XVII sajandi keeleloo jälgi (Ross 2007: 548). Seega on loomulik, et selles leidub ka mõningaid vanemale traditsioonile iseloomulikke jaatusega sümmeetrilise eituse näiteid.

\subsection{Minevikuvormid is / es}

Minevikku anti XVII sajandi põhjaeesti tekstide eitavates lausetes edasi vormiga is, mis esines muutumatuna. Samas näitab esinemissagedus, et selle partikliga väljendati negatsiooni harva: eitussõnaga is väljendatud tarindid moodustasid vaid 3\% (vt joonist 1 ).

Ainsaks selle aja põhjaeesti autoriks, kes vormi is negatsiooni vormistamiseks kasutas, oli Müller (näide 7). Siinse materjali põhjal otsustades vormistas ta partikliga is ainult eituse minevikuvorme. Ka Külli Prillop (2001: 95) on leidnud, et Müller tarvitas seda negatsioonisõna mineviku väljendamiseks. Põhiverb pöördus selliselt moodustatud negatsioonitarindis kahel korral ning oli konnegatiivne seitsmel korral. Mineviku eituspartiklile is võis Müller lisada ka partikli mitte, millel oli eitust fookustav või tugevdav roll. Stahli ega Blume teostes seda eitussõna ei ilmnenud, nemad väljendasid negatsiooni lihtminevikus partikliga ep või mitte ja lihtmineviku vormis põhiverbiga.

(7) [---] nĩck sen tö̈se Pöllu pæle is tulle mitte wichma, muito tæma kuÿwis erra. 'ning selle teise põllu peale ei tulnud vihma, vaid see kuivas ära' (VAKK, Müller13 1603: 6)

Gösekeni 1660. aasta grammatikas on eitussõnade juures ära toodud sarnase kirjakujuga sõna $i \beta$. Samas märgib ta selle partikli kohta, et see esineb üksnes kellegi keelamisel, nt iß keskis minna 'Er wil nicht gehen'. (Göseken 1660: 46, 67) See osutab partikli funktsiooni ümbertõlgendamisele ja võimalikule ahenemisele aja jooksul, mistõttu ei saa Gösekeni grammatikas toodud eitussõna ja Mülleri jutlustes tarvitatud partiklit is funktsionaalselt samastada. Hornungi grammatikas ei olnud vorm is eitussõnade juures välja toodud (vt nt Hornung 1693: 93).

XVIII sajandi põhjaeesti tekstides oli is asendunud vormiga es, mis moodustas siiski vaid $2 \%$ näidete koguarvust. Enamasti anti minevikku eitavates lausetes edasi partikliga ei või ep ning minevikus verbivormiga; negatsiooni tugevdati ühel korral ka partikliga mitte.

Es esines valimis vaid kahes töös kolmest: 1715 . aasta Uues Testamendis ning 1739. aasta täispiiblis (näide 8), kus selle eitussõnaga väljendati negatsiooni liht-, täis- ja enneminevikus. 
(8) Ja Jummala lamp es olle wel ärrakustutud Jehowa templis [---] 'Ja Jumala lampi ei olnud veel Jehoova templis ära kustutatud' (VAKK, Piibel 1739: 1Sm [III] 3)

Helle 1732. aasta keeleõpetuse dialoogide osas partiklit es ei leidunud, valimisse sattunud näited olid olevikus või täisminevikus ning nendes vormistati eitust partikliga ei. Selle keeleõpetuse adverbiloendis tuuakse vorm es teiste eitussõnade kõrval välja (Helle 1732: 57). Siiski osas, kus käsitletakse eituse moodustamist erinevates ajavormides, ei ole partikliga es ühtegi näidet (vt nt Helle 1732: 35-37 või 40), mis osutab, et Helle ja tema kaasautorid eelistasid anda negatsiooni minevikuvorme edasi teiste eituspartiklitega, nt ei.

Partikli es kasutamine mitmes XVIII sajandi põhjaeesti vaimulikus teoses eituse minevikuvormide väljendamiseks võib osutada lõunaeesti tekstide mõjule. See abisõna oli lõunaeesti pühakirjatõlgetes levinum kui põhjaeesti omades (Kilgi 2012: 118-119) ning juba enne Tallinna põgenemist Põhjasõja ajal sai osa Liivimaa vaimulikest oma kindralsuperintendendilt ülesandeks Johann Hornungi Uue Testamendi tõlge kopeerida ja seda parandada (Ross 2007: 547-548). Lisaks oli Wastne Testament kirjakeele reformis oluliseks eeskujuks (Ross 2013: 211-212).

Üldine minevikuvormide is ja es vähene esinemine põhjaeesti tekstides näitab, et nende tarvitamine mineviku eituse väljendamiseks ei olnud levinud ning nende asemel kasutati muid eitussõnu (nt $e p$ või $e i$ ).

\subsection{Polle}

Blume paistis XVII sajandi põhjaeesti autorite seast uuendusmeelsusega silma lisaks partikli ei kasutusele võtmisele ka negatsiooni väljendamisel vormiga polle 'pole', mis on kujunenud partikli ep ja verbi olema konnegatiivse vormi ühendist (Erelt 2017: 182). Blume oli siinses valimis ühtlasi ainus selle aja autor, kes polle-vormi tarvitas (näide 9). Seda vormi esines valimis kahel korral ning ilma partikliga mitte eitust tugevdamata. Hilisemal kontrollimisel ei leitud VAKK-ist XVI sajandi ega teiste XVII sajandi põhjaeesti autorite tekstidest vormi polle näiteid. Samas ilmnes Blume teose „Geistliche WochenArbeit” (vt nt 1666: 136) uurimisel, et seal on polle olemas.

(9) \# Nühd Surmal polle Weggi teps / \# sest hend ep kartket mitte [---] (VAKK, Blume 1667: 100)

Mõlemad valimisse sattunud näited olid olevikus, minevikuvormi, nt polnud, ei leidunud. See võib viidata, et polle esineski XVII sajandi keskpaigas muutumatuna. Kirjamehed võisid selle sõna minevikuvorme (nt polnud, pol$d u d$ ) veel mitte tunda või ei osanud nad neid moodustada. Gösekeni grammatikas on polle nimetatud, kuid samuti ainult olevikuvormis (Göseken 1660: 46). See iseenesest ei tähenda, et polle minevikuvormid poleks tollases rahvakeeles olemas olnud - need ei pruukinud olla veel kirjakeeles kasutusele võetud.

Mõlemad polle näited esinevad Blume 1667. aasta teose „Geistliche Hohe Fäst-Tahgs Freude” lauludes, nagu ka ei-eituse tarindid. Blume võis polle 
kasutusele võtta tänu selle vormi paremale riimilisele sobivusele. $E p+o l e$ on kokku kolmesilbiline, seevastu polle kahesilbiline. Kuigi polle minevikuvorme valimisse ei sattunud, viitab selle olevikuvormi esinemine nii Blume töödes „Geistliche Wochen-Arbeit” ja „Geistliche Hohe Fäst-Tahgs Freude” kui ka Gösekeni grammatikas, et polle oli XVII sajandi keskpaigas kirjakeelde juba kinnistumas ning ilmselt just laulude kaudu.

XVIII sajandil tõusis polle kasutus märgatavalt (vt joonist 1). Kui XVII sajandi põhjaeesti tekstides leidus vormi polle vaid 1\%-1 kõigist valimis sisaldunud näidetest, siis XVIII sajandi põhjaeesti teostes oli selle osakaal 8\%. Seda vormi oli tarvitatud eituse väljendamiseks nii 1715. aasta Uues Testamendis, Helle jt 1732. aasta keeleõpetuse dialoogide osas (näide 10) kui ka 1739. aasta täispiiblis.

(10) P. Eks sulle siis enne polnud öigest usko mitte? 'Kas sul siis enne polnud õiget usku?' (Hast du denn vorhero nicht den rechten Glauben gehabt?) (VAKK, Helle 1732: 416.186)

XVIII sajandi põhjaeesti tekstides kasutati polle-vormi mitmekesisemalt kui XVII sajandi põhjaeesti teostes (vt tabelit 4). Erinevalt XVII sajandi põhjaeesti tekstidest, kus seda vormi leidus ainult olevikus, esines polle XVIII sajandi põhjaeesti töödes ka imperfektis, perfektis ning pluskvamperfektis, nt polnud hapnend. Samuti oli polle-vormi tarvitatud umbisikulises tegumoes (1 korral 24-st). Partikkel mitte fookustas või intensiivistas negatsiooni. 1739. aasta täispiiblis oli vormile polle lisatud kolmel korral ka rõhutav gi-liide. Teistest vaadeldud XVIII sajandi põhjaeesti tekstidest gi-liitega polle-vormi valimisse ei sattunud. Sarnaselt Tiit Hennoste (2009) leitule pole kasutamise kohta suulises keeles ilmnes ka siinses töös, et polle kaldus esinema fookustatuse korral. Esile oli tõstetud polle ise või mõni muu lauseosa.

Tabel 4 .

\section{Vormi polle tarvitus XVIII sajandi põhjaeesti tekstides}

\begin{tabular}{|l|c|c|c|c|}
\hline Tekst & $\begin{array}{c}\text { polle } \\
\text { olevikus }\end{array}$ & $\begin{array}{c}\text { polle liht- } \\
\text { minevikus }\end{array}$ & $\begin{array}{c}\text { polle täis- } \\
\text { minevikus }\end{array}$ & $\begin{array}{c}\text { polle enne- } \\
\text { minevikus }\end{array}$ \\
\hline 1715. a UT & 1 & - & 1 & - \\
\hline 1732. a keeleõpetus & 4 & 1 & 1 & - \\
\hline 1739. a täispiibel & 9 & - & 5 & 2 \\
\hline Kokku & 14 & 1 & 7 & 2 \\
\hline
\end{tabular}

\subsection{Imperatiivivormid erra- / ̈̈rra- ja ep-keeld}

XVII sajandi põhjaeesti tekstide eitavates lausetes anti käsku edasi põhiliselt sõnaga erra 'ära', mis moodustas $25 \%$ kõigist valimisse kuulunud selle aja eitustarinditest. Erra esines tolle aja tekstides muutumatuna ning sellega vormistasid keeldu nii Müller (näide 11), Stahl kui ka Blume. 
(11) Sedda erralaße sina sinu Süddamest mitte erra tulla, erranis pea ickex meles [---] 'Seda ära lase oma südamest mitte lahkuda, vaid pea igavesti meeles' (VAKK, Müller7 1602: 7)

Põhiverb oli eitussõnaga erra väljendatud negatsioonis rohkem konnegatiivne (50 näitelauset) kui pöördetunnusega (25 näitelauset). Partikkel mitte toimis keelu edasiandmisel negatsiooni tugevdajana.

XVII sajandi põhjaeesti tekstidest sattus valimisse ka kaks ep-keelu näidet, mis pärinesid Stahli teose „Hand- vnd Haußbuch” II osast (näide 12) ning Blume tööst „Geistliche Hohe Fäst-Tahgs Freude” (näide 13). Stahl võis partiklit ep kasutada keelu märkimiseks lause selguse huvides. Näites 12 järgneb partiklile ep afiksaaladverb erra. Kaks sõna erra kõrvuti oleks võinud lugejas segadust tekitada, eriti kui tegemist polnud tema emakeelega. Samas Blumelt pärinevas laulureas teosest „Geistliche Hohe Fäst-Tahgs Freude” ühendverbi eitussõnale ei järgne (näide 13). Teda võis mõjutada tarindiga ep mitte eitavat käsklauset väljendama selle parem riimiline sobivus.

(12) [---] see wainlane münd ep errapettackut [---] ([---] Der Feind mich nicht erschleiche [---]) 'vaenlane ärgu mind eksitagu' (VAKK, Stahl 1637: 173)

(13) \# Nühd Surmal polle Weggi teps / \# sest hend ep kartket mitte [---] (\# Der Tohd hat keine Kraft nicht mêer / \# ihr dürffet ihn nicht scheuen [---]) 'Nüüd surmal pole väge teps, sellepärast ärge kartke' (VAKK, Blume 1667: 100)

Partikli $e p$ ja konstruktsiooni ep mitte vähene esinemissagedus keelu väljendamisel osutab, et selles funktsioonis kasutati XVII sajandi põhjaeesti tekstides rohkem eitussõna erra. Sellele viitab ka vormide ep ja ep mitte esinemus Gösekeni grammatikas. Kuigi Göseken on oma grammatika adverbide osas need eitusvormid keeldu väljendavate sõnadena välja toonud, ei ole ta neid ära märkinud imperatiivi käsitluse juures, kus näited on ainult sõnaga erra (Göseken 1660: 51, 65).

Ka XVIII sajandi põhjaeesti teostes anti eitavat käsku edasi sõnaga ärra, selline keeld moodustas $28 \%$ valimist. Kui XVII sajandi põhjaeesti teostes esines erra ainult muutumatu sõnana, siis XVIII sajandi põhjaeesti töödes oli sellele lisatud ka pöördetunnuseid. Samas leidus ka XVIII sajandi põhjaeesti teostes üksikuid näiteid, kus sõnal ärra pöördetunnus puudus, kuigi põhiverbil oli see olemas; eitavat käsklauset vormistati eitussõnaga ärra kõigis vaadeldud selle aja põhjaeesti tekstides (näide 14). Negatsiooni tugevdamiseks või fookustamiseks võidi lisada ka partikkel mitte.

(14) Sepärrast ärge kartke mitte; Teie ollete parramad / kui mitto Warblast. (VAKK, UT 1715: Lk [XII] 7)

Põhiverb võis olla nii konnegatiivne kui ka pöördetunnusega (vt tabelit 5). Konnegatiivset põhiverbi leidus 30 korral ainsuse 2. isikule suunatud keeldudes. Pöördetunnusega põhiverb oli eitavates käsklausetes 53 korral ning esines nii ainsuse 2 . isikus, mitmuse 1 . isikus kui ka mitmuse 2 . isikus. 
Põhiverbi vormi sagedus sõnaga ärra eitustarindites

\begin{tabular}{|l|c|c|}
\hline Tekst & $\begin{array}{c}\text { Konnegatiivne } \\
\text { põhiverb }\end{array}$ & $\begin{array}{c}\text { Pöördetunnusega } \\
\text { põhiverb }\end{array}$ \\
\hline 1715. a UT & 12 & 23 \\
\hline 1732. a keeleõpetus & 2 & 1 \\
\hline 1739. a täispiibel & 16 & 29 \\
\hline Kokku & 30 & 53 \\
\hline
\end{tabular}

XVIII sajandi tekstides ep-keeldu enam ei esinenud. Ka Helle jt toovad oma 1732. aasta keeleõpetuse grammatikaosas välja, et keeldu ei väljendata mitte partiklitega ei või ep, vaid sõnaga ärra (Helle 1732: 36). Ilmselt oli XVIII sajandiks ep-keeld taandunud, mida näitas ka Kilgi uurimus (2012: 124-125, 127).

\subsection{Eitavad küsipartiklid eps / eks 'kas ei'}

Siinse uurimuse XVII sajandi põhjaeesti materjalis vormistati üldküsilausetes negatsiooni partikliga eps, mis koosneb eitussõnast ep ning kliitikust -s (Metslang jt 2011: 156). Selle eitava küsipartikliga moodustati $4 \%$ kõigist valimisse kuulunud selle aja eitavatest lausetest. Partikkel eps esines küsilausetes lausealgulises positsioonis, sellega vormistati põhiliselt sümmeetrilist negatsiooni. Põhiverb oli pöördetunnusega 10 korral ning ühel korral konnegatiivne, ühel korral oli põhiverb ka $d a$-infinitiivis. Partikliga mitte intensiivistati seda negatsioonikonstruktsiooni kahel korral.

Partikliga eps olid oma töödes eitust edasi andnud Stahl (näide 15) ning Blume. Blume võis selle küsisõna kasutusele võtmisel järgida Stahli, kes oli tollel ajal üks autoriteetsemaid kiriklikke autoreid (Habicht 2001: 18). Mülleri jutlustes partiklit eps ei leidunud. Ka XVII sajandi keelekirjelduste grammatikaosades ei olnud partiklit eps käsitletud (vt nt Göseken 1660: 41-52; Hornung 1693: 93-94). Selle eitusvormi puudumine tollastest keeleõpetustest võib osutada, et sellest kui Stahli-pärasest vormist püüti eemalduda. Samas on Kilgi (2012: 116) märkinud, et eps leidub Pilistvere käsikirjas (1687), mis esindab Uue Testamendi konservatiivset põhjaeestikeelset varianti (Ross 2013: 211). Arvatavasti on partikli eps esinemine seal tingitud Stahli keelekasutuse autoriteedist.

(15) Eps se ello eñamb on kudt se rohgk? (Jst nicht das Leben mehr denn die Speise?) 'Kas elu ei ole enamat kui toit?' (VAKK, Stahl 1638III: 124)

XVIII sajandi põhjaeesti teostes oli eps asendunud partikliga eks, mida esines valimis 7\%-l selle aja näidete koguarvust (vt joonist 1). Eks on kujunenud eitust väljendavast tüvest $e$-, küsivast kliitikust $-k O$ ning kinnitavast 
kliitikust -s (Metslang jt 2011: 155). Erinevates piiblitõlgetes esineb eks alates 1694. aasta Müncheni käsikirjast (Kilgi 2012: 116), seega võis muutus eitava küsipartikli valikus alguse saada just sellest Hornungi-mõjulisest käsikirjaversioonist. Partikliga eks moodustati negatsiooni nii 1715. aasta Uues Testamendis, Helle jt 1732. aasta keeleõpetuse dialoogide osas (näide 16) kui ka 1739. aasta täispiiblis. Kuigi Helle jt grammatikaosas ei olnud eks eraldi välja toodud, ${ }^{4}$ leidus see partikkel sõnastikuosas kui küsiv eitussõna (Helle 1732: 89).

(16) Eks sa woi ennast sest surmast lahti peästa? (Kanst du dich dann von diesem Tode nicht frey machen?) (VAKK, Helle 1732: 407.117)

Nagu eps, nii esines ka eks küsimustes lausealgulises positsioonis. Põhiverb oli partiklit eks sisaldavates lausetes ainult konnegatiivne. Seega oli ka selle üldküsilause konstruktsiooni põhjal otsustades XVIII sajandiks kaugenetud saksapärasest jaatusega sümmeetrilisest negatsioonist. Lisaks konnegatiivsele verbivormile leidus põhiverbi ka imperfektis ja perfektis. Partiklit mitte tarvitati negatsiooni intensiivistamiseks vaid ühel korral.

\subsection{Muutused põhiverbi vormi valikul ja eitusvormide varieerumisel}

Põhiverbi vormi kasutuse teisenemine XVII-XVIII sajandi jooksul on kokkuvõtvalt näha joonisel 2. Siinsest uurimusest ilmnes, et lisaks eituspartiklite ja -tarindite rahvapärasema kasutuse suurenemisele oli sama suundumust märgata ka verbivormi valikus.

Kui XVII sajandi põhjaeesti tekstides oli negatsioon peaaegu võrdselt nii jaatusega sümmeetriline kui ka asümmeetriline (valimis vastavalt 141 ja 126 korda), siis XVIII sajandi põhjaeesti teostes eelistati ülekaalukalt eestipärasemat asümmeetrilist eitust: konnegatiivset põhiverbi kasutati sel sajandil üle nelja korra rohkem kui pöördetunnusega põhiverbi (valimis vastavalt 165 ja 37 korda). Kasutusviisi muutus näitab, et keelereformi käigus läheneti uuendusmeelsete kirjameeste seisukohtadele ning võeti nende verbivormi puudutavad parandusettepanekud omaks.

Minevikuvormis põhiverbi leidus mõlemal sajandil: 23 korral XVII sajandil ning 45 korral XVIII sajandil ja see võis esineda nii liht-, täis- kui ka enneminevikulistes eituslausetes.

Lisaks sümmeetrilise negatsiooni taandumisele oli XVII-XVIII sajandi jooksul märgata ka varieeruvuse mõningast vähenemist eituse väljendamisel (vt joonist 1). Kui XVII sajandil tarvitati erinevas kõneviisis ja ajas eituse moodustamiseks üheksat erinevat partiklilist vormi, siis XVIII sajandil kuut erinevat: negatsiooni vormistati ülekaalukalt partikliga $e i$, teiste eitussõnade ja -tarindite osakaal oli sellega võrreldes mitu (mõnel juhul ka mitukümmend) korda väiksem.

\footnotetext{
${ }^{4}$ Helle oli seda sõna kasutanud ühes näitelauses daativist kõneldes (vt Helle 1732: 70).
} 


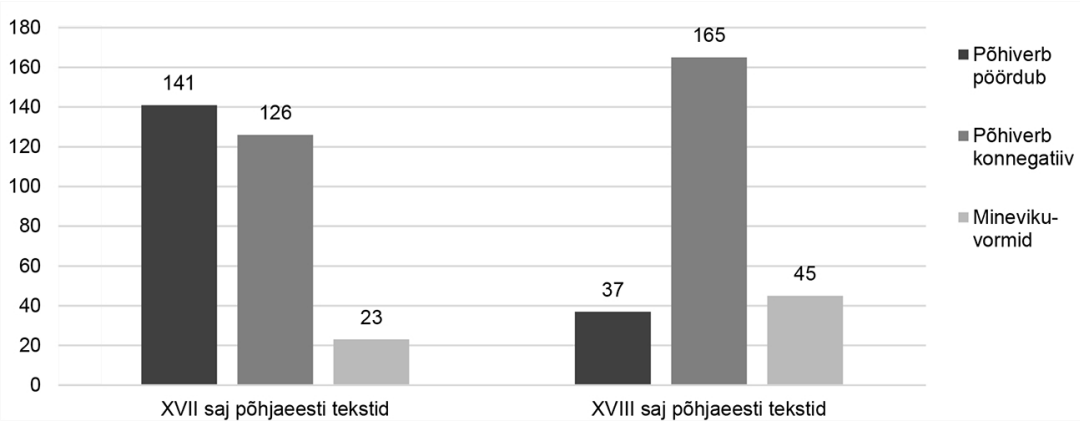

J o on is 2. Põhiverbi vorm XVII-XVIII sajandi põhjaeesti tekstides. ${ }^{5}$

Tendents jaatusega asümmeetrilise negatsiooni suunas ning varieerumise vähenemine eituse väljendamisel oli tingitud 1680-ndatel alanud eesti kirjakeele ajakohastamisest ja reformimisest, mis tipnes 1739 . aasta täispiibli ilmumisega. Sellele osutavad tolle aja keelekäsitlustes väljendatud seisukohad. Hornung (1693: 74) tõi oma grammatikas välja, et eitussõnaga ei või ep lausetes kaob verbist viimane konsonant, mõeldes sellega pöördetunnust. Samal arvamusel olid verbivormi suhtes Helle jt (1732: 35). Ka ei märgitud kummaski teoses, et eitust saab edasi anda saksa keele eeskujul ainult partikliga mitte (vt nt Hornung 1693: 93; Helle 1732: 57). Helle jt 1732. aastal avaldatud teose keelelised seisukohad rakendusid 1739. aasta täispiiblis, mille trükki toimetamist Helle suunas (Ross 2006: C26). Ka Kilgi (2012: 130) uurimus kinnitab, et muutus rahvapärasemate eitussõnade ja asümmeetrilise negatsiooni suunas toimus 1680. aastate lõpul ehk siis, kui asuti teadlikumalt keele reformimisega tegelema.

Kuigi alguses uuendusmeelsete kirjameeste seisukohad valitsema ei pääsenud (vt nt Piiblikonverentsid 2003: 89-90, 93), leidsid need kindla koha 1715. aasta Uues Testamendis, mis ilmus Forseliuse-Hornungi kirjaviisis (Piiblikonverentsid 2003: 11), ning domineerisid täielikult 1739. aasta täispiiblis, mille keel peegeldab tolleks ajaks välja kujunenud keeleideaali (Ross 2006: C26).

\section{Kokkuvõte}

Artiklis vaadeldi negatsiooni väljendamise viise ning nende varieerumist XVII-XVIII sajandi põhjaeesti kirjakeele vaimulikes ning õpetlikes teostes, keskendudes lauseeitusele ning lähtudes põhilistest eitussõnadest ja -vormidest. Eesmärk oli välja selgitada, milliste partikliliste tarinditega väljendatakse negatsiooni ning kuidas eitusvormide kasutus kahe sajandi jooksul muutub. Samuti jälgiti tollase kirjakeele normi väljakujunemist eituse varieerumise põhjal ning autorite keelekasutuse eripära.

${ }^{5}$ Joonise 2 arvandmete hulka ei ole arvatud polle-vorme ega pöördetunnuseta vorme, nagu nt $d a$-infinitiiv. 
Uurimusest ilmnes, et eitust väljendati XVIII sajandil rahvapärasemalt, nt saksaeeskujulise sümmeetrilise negatsiooni asemel tarvitati sellel ajal ülekaalukalt jaatusega asümmeetrilist eitust. Samuti taandusid kasutusest mõned vormid (nt mitte-negatsioon) ja eituse edasiandmisel vähenes varieerumine üheksalt partikliliselt vormilt kuuele.

Nende põhjaeesti kirjakeeles toimunud muutuste põhjuseks oli 1680-ndatel alanud kirjakeele uuendamine ning uuenduslikkust taotlevate kirjameeste (nt Forseliuse, Hornungi) tegevus, millele viitavad ka erinevad selle aja keeleõpetuse seisukohad. Samas oli uuendusmeelsuse ilminguid näha juba XVII sajandi keskpaiga autoril Blumel, kes võttis esimesena põhjaeesti autoritest oma tekstides kasutusele eitussõnad ei ja polle.

Märgendatud 600 näitega valimi sobivust negatsiooninähtuste varieerumisest ülevaate saamiseks kinnitavad siinse käsitluse ja varasemate uurimuste (nt Kilgi 2012) samasuunalised tulemused. See osutab, et sarnastel põhimõtetel koostatud valim võiks sobida ka edasises uurimistöös muude morfosüntaktiliste nähtuste läbilõikeliseks käsitlemiseks.

Artiklis joonistus selgelt välja kirjakeele tollases kujunevas standardis toimunud eituse väljendamise muutus, mis avaldus suundumuses rahvapärasemate vormivalikute ja jaatusega asümmeetrilise negatsiooni poole (vt joonised 1 ja 2).

Siinsest artiklist jäid välja XVIII sajandi põhjaeesti ilu- ja tarbekirjanduse tekstid. Edasist uurimist vajaks, kuidas eituse vormistamine varieerub nendes teostes ning kas tulemused erinevad vaimulike tekstidega võrreldes. Samuti vajaks põhjaeesti vanemas kirjakeeles ulatuslikumat uurimist, missugused tegurid tingivad vormi polle esinemise. Selle vormi vaatlusse tuleks kaasata kõik VAKK-is leiduvad XVII-XIX sajandi põhjaeesti tekstid, et oleks selgemini näha võimalikud mitmesaja aasta jooksul toimunud muutused.

Artikli valmimist on toetanud projekt PUT475 „Kirjakeele morfosüntaksi varieerumise integreeritud mudel: pilootuuring eesti keele näitel”.

\section{Lühendid}

$\mathrm{Jh}=$ Johannese evangeelium

2Jh [IV] 5 = Johannese kiri heebrealastele

Lk [XII] 7 = Luuka evangeelium

$1 \mathrm{Sm}=1$. Saamueli raamat

\section{Kirjandus}

Barlow, Michael, Kemmer, Suzanne 2000. Usage Based Models of Language. Stanford: CSLI Publications.

Bl u m e, Christoph 1666. Geistliche Wochen-Arbeit. Leipzig: S. Spörel. http://www. digar.ee/arhiiv/nlib-digar:284693 (30. IX 2017).

Bybee, Joan L. 2010. Language, Usage and Cognition. Cambridge: Cambridge University Press. 
B y bee, Joan L., B eckner, Clay 2010. Usage-based theory. - The Oxford Handbook of Linguistic Analysis. Oxford: Oxford University Press, lk 827-856.

Cou s sé, Evie, Mengd en, Ferdinand von 2014. Usage-Based Approaches to Language Change. Amsterdam-Philadelphia: John Benjamins.

Erelt, Mati 2017. Eitus. - Eesti keele süntaks. (Eesti keele varamu III.) Toim M. Erelt, Helle Metslang. Tartu: Tartu Ülikooli Kirjastus, lk 181-195.

Göseken, Heinrich 1660. Manuductio ad Linguam Oesthonicam, Anführung Zur Öhstnischen Sprache. Reval: A. Simon. http://www2.kirmus.ee/grafo/index. php?ID=243 (25. IX 2017).

Habicht, Külli 2001. Eesti kirjakeele leksikaalsest ja morfosüntaktilisest arengust ning Heinrich Stahli keele eripärast selle taustal. (Dissertationes philologiae estonicae universitatis Tartuensis 10.) Tartu: Tartu Ülikooli Kirjastus.

Habicht, Külli, Penja m, Pille, Prillop, Külli 2015. Heinrich Stahli tekstide sõnastik. Tartu: Tartu Ülikooli Kirjastus.

Helle, Anton Thor 1732. Kurtzgefaszte Anweisung Zur Ehstnischen Sprache. Halle: Stephan Orban. http://www.digar.ee/arhiiv/nlib-digar:100071 (25. IX 2017).

Hennoste, Tiit 2009. ei ole ja pole kasutus suulises spontaanses eesti keeles. - Emakeele Seltsi aastaraamat 54 (2008). Tallinn: Teaduste Akadeemia Kirjastus, lk 72-93.

Hornung, Johann 1693. Grammatica Esthonica, brevi, Perspicua tamen methodo ad Dialectum Revaliensem. Riga. [Faksiimileväljaanne: Johann Hornung. Grammatica Esthonica, brevi, Perspicua tamen methodo ad Dialectum Revaliensem. Riga 1693. Eingeleitet und herausgeben von Harald Haarmann. Hamburg: Helmut Buske Verlag, 1977.]

Kas k, Arnold 1970. Eesti kirjakeele ajaloost I. Tartu.

Kilgi, Annika 2012. Eitusvormid 17.-18. sajandi eesti piibliversioonides. (Tallinna Ülikooli eesti keele ja kultuuri instituudi toimetised 13.) Tallinn: Tallinna Ülikool, lk 106-137.

King i s e p p, Valve-Liivi, Prill o p, Külli, H a bi c h t, Külli 2004. Eesti vana kirjakeele korpus: mis tehtud, mis teoksil. - Keel ja Kirjandus, nr 4, lk 272-280.

La a nekask, Heli 2004. Eesti kirjakeele kujunemine ja kujundamine 16.-19. sajandil. (Dissertationes philologiae estonicae universitatis Tartuensis 14.) Tartu: Tartu Ülikooli Kirjastus.

Lill, Anne 1988. Christoph Blume ja XVII sajandi eesti kirjakeel. - Keel ja Kirjandus, nr 1, lk 7-17.

Mets lang, Helle, Habi cht, Külli, Pajus al u, Karl 2011. Developmental paths of interrogative particles: The case of Estonian. - Folia Linguistica Historica, $\mathrm{kd}$ 32 , lk 149-187.

Miest a m o, Matti 2005. Standard Negation: The Negation of Declarative Verbal Main Clauses in a Typological Perspective. Berlin-New York: Mouton de Gruyter.

Miestam o, Matti 2009. Negation. - Grammar, Meaning and Pragmatics. Toim Frank Brisard, Jan-Ola Östman, Jef Verschueren. Amsterdam-Philadelphia: John Benjamins, lk 208-229.

Penjam, Pille 2010. Eituskategooria Heinrich Stahli eesti keeles. - Emakeele Seltsi aastaraamat 55 (2009). Tallinn: Teaduste Akadeemia Kirjastus, lk 138160 . 
Piiblikonverentsid 2003 = Piiblikonverentsid ja keelevaidlused. Põhjaeestikeelse Piibli tõlkimise ajaloost (1686-1690). Allikapublikatsioon. Koost Leino Pahtma, Kai Tafenau. Tartu: Eesti Ajalooarhiiv.

Prillo p, Külli 2001. Georg Mülleri jutluste verbivormistik. Magistritöö. Käsikiri Tartu Ülikooli eesti ja üldkeeleteaduse instituudis.

R a a g, Raimo 2008. Talurahva keelest riigikeeleks. Tartu: Atlex.

Reila, Heiki 2007. Müncheni käsikirjast ja selle seostest Johann Hornungi tõlkega: keelelisi tähelepanekuid. - Põhjaeestikeelsed Uue Testamendi tõlked 1680-1705. Koost Kristiina Ross. Toim H. Reila, K. Ross, Kai Tafenau. Tallinn: Eesti Keele Sihtasutus, lk 556-563.

Re i m a n, Villem 1895. Bengt Gottfried Forselius. - Eesti Üliõpilaste Seltsi Album. Kolmas leht. Trükitud Eesti Üliõpilaste Seltsi kuluga, lk 7-52.

Ross, Kristiina 2006. „Lühike sissejuhatus” ja eesti piiblitõlge. - Lühike sissejuhatus eesti keelde 1732. Saksa keelest tõlkinud ja järesõna kirjutanud Annika Kilgi ja K. Ross. Tallinn: Eesti Keele Sihtasutus, C26-C53.

Ross, Kristiina 2007. Rootsiaegsete põhjaeestikeelsete Uue Testamendi tõlkekäsikirjade osast eesti kirjakeele kujunemisloos. - Põhjaeestikeelsed Uue Testamendi tõlked 1680-1705. Koost K. Ross. Toim Heiki Reila, K. Ross, Kai Tafenau. Tallinn: Eesti Keele Sihtasutus, lk 545-550.

R os s, Kristiina 2009. Eesti keel Henrikust Anton Thor Helleni. - Keel ja Kirjandus, nr 8-9, lk 553-558.

R os s, Kristiina 2011. Missioon ja mäng eesti kirjakeele sünnis. - Vikerkaar, nr 1-2, lk 117-127.

Ross, Kristiina 2013. Vanad uuendused lõuna- ja põhjaeesti keeles. - Emakeele Seltsi aastaraamat 58 (2012). Tallinn: Teaduste Akadeemia Kirjastus, lk 210-224.

Zi e gel m a n n, Katja 2008. Eitusest eesti vanas kirjakeeles. - Koolitus ku keele ja kultuuri umamoodu hoitja. Haridus keele ja kultuuri omapära hoidjana. (Võro Instituudi toimõndusõq 22.) Toim Jüvä Sullõv. Võro: Võro Instituut, lk 84-96.

Zi e gel m a n n, Katja 2011. Die Verneinung im Estnischen: Zum Abbau des finiten Verneinungsverbs im älteren Schriftestnischen. Dissertation. Göttingen. http:// hdl.handle.net/11858/00-1735-0000-0006-AEDC-7 (1. X 2017).

T a fen a u, Kai 2011. Et tõlkida piiblit eesti ja läti keelde... - Tuna, kd 14, nr 1, lk 41-59.

\section{Allikad}

VAKK = Vana kirjakeele korpus. http://www.murre.ut.ee/vakkur/Korpused/korpused.htm (15. X 2017):

Bl u me, Christoph 1662. Das Kleine Corpus Doctrinæ. Reval: A. Simon.

Blu m e, Christoph 1667. Geistliche Hohe Fäst-Tahgs Freude. Leipzig: S. Spörel. Helle 1732 = Kurtzgefaszte Anweisung Zur Ehstnischen Sprache, V. Colloquia

Esthonica. Halle: Stephan Orban.

Müller, Georg 1600-1606. Jutluste käsikiri.

Piibel 1739 = Piibli Ramat, se on keik se Jummala Sanna, mis Pühhad Jummala

Mehhed, kes pühha Waimo läbbi juhhatud, Wanna Seädusse Ramatusse Ebrea Kele ja Ue Seädusse Ramatusse Kreka Kele essite on ülleskirjotanud, 
nüüd agga hopis, Jummala armo läbbi, meie Eesti- Ma Kele Essimest korda üllespandud, ja mitme sündsa salmiga ärraselletud. Tallinn: J. J. Köhler.

St a hl, Heinrich 1632-1638. Hand- vnd Haußbuch I-IV. Riga-Reval.

St a hl, Heinrich 1641, 1649. Leyen Spiegel I-II. Reval.

UT 1715 = Meie Issanda Jesusse Kristusse Uus Testament Ehk Jummala Ue

Sädusse Sanna 1715. Tallinn: J. C. Brendeken.

Liina Pärismaa (snd 1988), MA, Tartu Ülikool, eesti ja soome-ugri keeleteaduse doktorant, liina.parismaa@ut.ee

\section{The form choices of the expression of negation in the $17^{\text {th }}$ and $18^{\text {th }}$-century North Estonian texts}

Keywords: old literary language, negation, variation, usage-based method

This article deals with the expression of clausal negation and its variation in the $17^{\text {th }}$ - and $18^{\text {th }}$-century North Estonian ecclesiastical and didactical texts. The aim of this study is to find out which forms convey clausal negation, how their usage changes during the two centuries, and how large the extent of variation is in the scope of particle-like negation forms. The broader goal is to observe how the literary standard develops during that time.

This study is usage-based and explores 600 different negation clauses (300 tagged examples from either century). The negation forms were chosen randomly from the Corpus of Old Written Estonian.

It was found that during the 200 years the expression of negation changed more towards the vernacular language and the effect of German diminished. Symmetric negative constructions were replaced with asymmetric ones and the extent of variation decreased from nine different particle-like negation forms to six different forms.

Some negation forms disappeared by the beginning of the $18^{\text {th }}$ century (e.g. mitte) and others appeared (e.g. eks). The usage of the native negation form ei increased considerably. The change towards vernacular use was apparent in lexical verb forms as well. During the $17^{\text {th }}$ and $18^{\text {th }}$ centuries the authors started to use more connegative verb forms instead of the inflected ones.

The tendency towards more native usage of negation and the diminishing of variation were caused by the literary language reform, which started at the end of the $17^{\text {th }}$ century and ended in 1739 , when the first North Estonian full Bible was published.

Liina Pärismaa (b. 1988), MA, University of Tartu, doctoral student of Estonian and Finno-Ugric Linguistics, liina.parismaa@ut.ee 